\title{
Current conservation policies in the UK and Ireland overlook endangered insects and are taxonomically biased towards Lepidoptera
}

\author{
Natalie Duffus ${ }^{1}$ and Juliano Morimoto ${ }^{1}$ \\ ${ }^{1}$ University of Aberdeen
}

February 11, 2022

Authors: Natalie E. Duffus ${ }^{1}$, Juliano Morimoto ${ }^{1,2^{*}}$

Authors' Affiliations:

School of Biological Sciences, University of Aberdeen, Zoology Building, Tillydrone Ave, Aberdeen AB24 $2 \mathrm{TZ}$

Programa de Pós-graduação em Ecologia e Conservação, Universidade Federal do Paraná, Curitiba, 82590300, Brazil

*Correspondence: juliano.morimoto@abdn.ac.uk

Authors' contributions. ND and JM designed the study. ND collected and analysed the data and wrote the first draft of the manuscript. Both authors contributed to the writing of the final version of the manuscript and approved its submission.

Declaration of interest: We wish to confirm that there are no known conflicts of interest associated with this publication and there has been no significant financial support for this work that could have influenced its outcome.

Funding Statement: This research did not receive any specific grant from funding agencies in the public, commercial, or not-for-profit sectors.

\begin{abstract}
Insects provide key ecosystem services for our sustainable future, which rely upon effective conservation policies to protect insect biodiversity. To date, however, we still do not know how effective current conservation policies are for protecting insect biodiversity, opening up the possibility that policies are unfit-for-purpose. Given the considerable debate and public awareness on the potential global decline of insect species, it is important to understand whether or not current policies can protect insect biodiversity. Here, we used IUCN listing of species status and developed a quantitative framework to analyse the potential effectiveness and coverage of current conservation policies pertaining to insect biodiversity in the UK and Ireland. We contrasted this against coverage for a well-known group - mammals - as a benchmark, to find that while the vast majority of the UK mammalian species in the European IUCN red list are directly protected by current policies, insects remain largely unprotected. Moreover, for those insect species that are explicitly protected by current policies, there is a taxonomic bias whereby the majority $(>50 \%)$ of insect species are Lepidopterans (moths and butterflies), while a minority are Coleopterans (beetles), and none are Hymenopterans (bees, ants, wasps). Similar trends were observed in the UK priority biodiversity lists. Based on our data, we conclude that current biodiversity policies in the UK and Ireland have significant gaps in their protection of
\end{abstract}


insect biodiversity and, there is a taxonomic bias that may skew some conservation efforts towards butterflies and moths. We anticipate that our findings are likely to occur worldwide, highlighting the need for more directive policies to manage and protect insect biodiversity for the sustainability of ecosystem services.

Keywords: Environmental Policy, Entomology, Taxonomic Bias, Conservation Priorities

\section{Introduction}

In our changing world, there are a number of pressures threatening insect biodiversity, including habitat degradation and loss, pollution and climate change (Cardoso et al., 2020). These current drivers, may result in declining insect populations, adversely affecting the functioning of ecosystems (van der Sluijs, 2020; Vanbergen, 2013). The roles filled by insects within the ecosystem are essential not only for ecosystem health, but also the sustainable development of our societies (Schowalter, 2013; Soliveres et al., 2016) provided that insects are responsible for the provisioning of unconventional services to society that span from plastic degradation through to cultural heritage (Bombelli et al., 2017; Duffus et al., 2021; Noriega et al., 2018) [see also (Morimoto, 2020) for a review]. These functions and services may be threatened by losses in insect biodiversity. For instance, in the UK, environmental changes affecting the timing of peak activity in bees has led to the extinction of 13 bee and 10 flower-visiting wasp species (Balfour et al., 2018; Ollerton et al., 2014), alongside declines in hoverflies (Powney et al., 2019), moths (Bell et al., 2020; Dennis et al., 2019) and beetles (Brooks et al., 2012; Brown and Roy, 2015; Gardiner and Didham, 2020). These species are important ecosystem service providers and thus, their extinction can have long-lasting impact in the stability of the ecosystem (van der Sluijs, 2020; Vanbergen, 2013). Likewise, many butterfly species that have been considered as declining or having undergone extinction are specialists as opposed to generalists, the latter which have remained relatively more stable (Brereton et al., 2011). This suggests that specialist butterfly species might be more vulnerable to ongoing climatic changes and declining at a faster rate than generalists (known as "functional homogenisation") (McKinney and Lockwood, 1999), which can unbalance the long-term provision and sustainability of ecosystem functions that depend on specialist species and/or a stable, functionally rich, community of insects (Clavel et al., 2011; Manning et al., 2016; Soliveres et al., 2016).

While the extent and interpretation of global insect declines has been extensively debated (Bell et al., 2020; Daskalova et al., 2021; Didham et al., 2020; Montgomery et al., 2020), there is consensus that action needs to be taken to conserve insect biodiversity (Cardoso et al., 2020; Forister et al., 2019; Habel et al., 2019; Samways et al., 2020). Not only because insects fill a crucial functional role within the ecosystem (Schowalter, 2013; Soliveres et al., 2016; Seibold et al., 2021), but also for the intrinsic value of the species diversity on earth (Senapathi et al., 2015; Batavia and Nelson, 2017). To prevent further such losses to the entomofauna, conservation efforts for insect biodiversity are required. A key tool for bringing insect conservation into the (global) agenda is through conservation policies that guide efforts and create binding agreements for action toward the conservation of designated species. However, the effectiveness of such agreements for insect species conservation is unclear, with increasing support for the approach of tackling insect conservation in a wider, landscape-focused effort (Samways, 2015). This is because the inclusion of insects in species conservation policies can be challenging, owing to the barrier of policy-makers' perceptions and opinions of insects (Cardoso et al., 2011b). These perceptions can potentially render important policies such as the EU Habitats Directive biased in their coverage, neglecting important insect orders from their scope (Cardoso, 2012; Leandro et al., 2017). This can have a knock-on effect to funding allocation, for example only $0.06 \%$ of European invertebrates receiving LIFE project funding compared with $23 \%$ of vertebrates (Mammola et al., 2020). Additionally, a lack of baseline data to guide efforts can impede more general agricultural policies aiming to increase habitat connectivity and safeguard pollinators (Hall and Steiner, 2019; Cole et al., 2020). Ultimately, these political challenges may lead to conservation efforts which are biased to the detriment of insect biodiversity.

Despite the documented decline and extinction of UK insect species (Ollerton et al., 2014; Powney et al., 2019; Bell et al., 2020; Dennis et al., 2019; Brooks et al., 2012; Brown and Roy, 2015; Gardiner and Didham, 2020), to date, there has not been a full assessment of the scope and coverage of UK conservation policies in 
regard to insect biodiversity. Consequently, we still do not know whether or not current species conservation policies in the UK adequately protect and prioritise the breadth of insect biodiversity.

Here, we addressed this gap by exploring the scope of particular UK and Irish policies for conserving insect biodiversity, which can have long-lasting implications for the protection of insect biodiversity. In this study, we limited the scope to policies which delineate particular species of conservation concern. Although important, other more general policies, including those for protected areas, agricultural, and pollutant policies were excluded from our scope, as their effects on insect conservation are challenging to analyse and contrast against one another. For our analysis, we first identified policies to include, from which we extracted the species listed in these policies. The species list obtained from policies then allowed us to estimate taxonomic biases in insect groups. For comparison, we also extracted the mammal species listed by the policies. This provided us with a well-known group of animals with which to contrast the coverage of insects by the policies. Previously, mammals (and other vertebrates), have been found to garner more conservation support, which can translate into political action (Mammola, 2020; Donaldson, 2016; Martín-López et al., 2007) hence our choice of this benchmark group. The following policies that protect or prioritise insects within the UK and Ireland were identified and included: (i) Broad policies requiring the conservation of species on 'priority biodiversity lists' by public bodies. This includes the Natural Environment and Rural Communities Act 2006 for England, Nature Conservation Act 2004 for Scotland, Environment Act 2016 for Wales, and the Wildlife and Natural Environment Act 2011 for Northern Ireland. The species listed by these policies are regularly reviewed (approx. every 3 years) and listed or delisted using the most current data. Priority biodiversity lists aim to promote the conservation of species threatened with extinction, (ii) strict policies that legally protect species from killing, trade, or disturbance and transpose the obligations of the Bern Convention and EU Habitats Directive into law. This includes the Wildlife and Countryside Act 1981 in England, Wales, and Scotland, the Wildlife Order 1985 and Conservation (Natural Habitats, etc.) Regulations of 1995 in Northern Ireland, and the Wildlife Act 1976 in Ireland. Much like the priority biodiversity lists, the species listed by these policies are regularly reviewed (approx. every 5 years) using the most current data. We had no a priori reason to expect biases in the insect species listed by the policies but expected more charismatic species (e.g., butterflies) to be listed more often than species with no or negative public perception (e.g., flies). Overall, our data reveals gaps in conservation policies which can possibly render policies ineffective in protecting insect biodiversity. These legislative gaps may be widespread, highlighting the potential passive contribution of unfit policies to the current and future extinction rates of insects.

\section{Materials and Methods}

\subsection{Policy identification}

Figure 1 summarises the policies and their obligations. We conducted an analysis of policies in the UK and Ireland, by selecting policies which outline obligations related to a list of species. These policies either explicitly protect species from killing, trade, and disturbance, or set out a broader duty to conserve particular species. Although relevant to biodiversity conservation, we excluded more general policies including agricultural, pesticide, and pollutant policies. The effects of these policies on particular insect fauna are challenging to pinpoint, and thus we opted for a more focused scope in this study. Firstly, we identified the conservation policy in each UK country that requires the creation of lists of species of 'principal importance to conservation' (a.k.a. priority biodiversity lists). These are species which public bodies and stakeholders are encouraged to take steps to conserve. The priority lists were obtained from the following sources for each of the following policies: the Natural Environment \& Rural Communities (England) Act 2006 (Natural England, 2014), Nature Conservation (Scotland) Act 2004 (NatureScot, 2020), Environment Act (Wales) 2016 (Wales Biodiversity Partnership, 2021), and the Wildlife and Natural Environment Act (Northern Ireland) 2011 (DAERA, 2010). Beyond these, we identified UK legislation that serves to protect species which are directly threatened by human exploitation or disturbance. For England, Wales, and Scotland (with amendments), this policy is the Wildlife and Countryside Act 1981 whilst, Northern Ireland has the Wildlife Order 1985, in addition to the Conservation (Natural Habitats, etc.) Regulations of 1995. Further to protecting species, these policies also include obligations of international and European conventions including the Bern Convention (Council 
of Europe, 2020), which promotes the conservation of endangered species, and the EU Habitats Directive (European Commission, 2020), which is responsible for the protection of Annex IV species, and the designation of Special Areas of Conservation (SACs) in response to the presence of Annex II species. All UK policies were accessed in May 2021 from the UK Government Legislation website (https://www.legislation.gov.uk/). In Ireland, the Wildlife Act 1976 (Irish Statute Book, 2021) is primarily responsible for species conservation and was further strengthened by the introduction of the EU Habitats Directive. This policy assigns legal protection to species threatened by exploitation and direct human pressures. As of May 2021, Ireland did not have legislation we could identify that creates a legal responsibility for selection of priority conservation species such as those in the UK. Ireland was included due to its geographic proximity with other UK countries but policy independence relative to the UK.

\subsection{Insect data collection}

We used two complementary approaches to collate insect data from publicly available sources. First, we obtained data on the number of insect species present in the British Isles, encompassing both Great Britain and Ireland $(N=24043)$ for 31 insect groups (Barnard, 2011), allowing us to develop an analysis of potential taxonomic bias within the insects listed by policies. Next, we obtained red list data for Europe from the IUCN Red List of Threatened Species 2021-1 (IUCN, 2021). To obtain this data we used the "advanced search" feature, and "view all species", with the following search filters: "Regional Assessments: Europe", "Land Region: Europe: United Kingdom", "Taxonomy: Animalia: Arthropoda: Insecta". This gave us a downloadable list of the insect species found in the UK that have been assessed using the IUCN red list at the European level $(\mathrm{N}=548)$. The same protocol was followed but substituting "United Kingdom" for "Ireland" to obtain the data for Ireland and Northern Ireland analyses $(\mathrm{N}=211)$. To obtain IUCN data for mammals, the same geographic filters were applied but using "Taxonomy: Animalia: Chordata: Mammalia" (UK: N=81, Ireland: $\mathrm{N}=50)$. This approach wielded data for UK mammals $(\mathrm{N}=81)$ and insects $(\mathrm{N}=548)$, and Irish mammals $(\mathrm{N}=50)$ and insects $(\mathrm{N}=211)$.

While widely accepted and used, the IUCN Regional European assessment may be imprecise in its assessment of extinction risk for the UK and Ireland. To mitigate this, we also obtained assessments of extinction risks carried out on the national-level. This allowed us to assess the extinction risk of insects and mammals which are listed by policies in the UK and Ireland, to identify the prioritisation of endangered insects within law. For Scotland, England, and Wales, the Joint Nature Conservation Committee (JNCC) website hosts a spreadsheet of UK taxa and their conservation designations (JNCC, 2020). From this spreadsheet, the first column of 'taxon groups' on the sheet titled 'summary for each taxon' was filtered to include the listed 16 insect groups, and 6 mammal groups. This was then filtered further to only include those species with a UK level assessment of extinction risk, using IUCN regional criteria, using the three columns that denoted Red Listing based on pre-1994 IUCN guidelines, 1994 IUCN guidelines, and 2001 IUCN guidelines. Where groups had been assessed with multiple sets of guidelines, we used the most recent assessment for our analysis. This gave us a list of insect species $(N=2292)$ and mammal species $(N=59)$ that had had their extinction risk assessed. There were fewer mammals in this dataset than the European IUCN Red List, as it also pertained to cetaceans. Nine of the insect groups had been assessed using the 2001 IUCN guidelines (Lepidopteran butterflies, Coleoptera, Diptera, Trichoptera, Plecoptera, Hemiptera, Ephemeroptera, Odonata, Orthoptera). The remaining two (Hymenoptera and Lepidopteran moths) had most recently been assessed using pre-1994 IUCN guidelines but were still included since this was the most up-to-date assessment in which analyses for these groups were conducted. All mammals had been assessed with the most recent guidelines. A dataset was also created by collating the Irish red lists for insects $(N=1051)$ and mammals $(N=43)$ to study both Irish and Northern Irish policies (National Biodiversity Data Centre, 2020). Irish red lists included aquatic Coleoptera (Foster, Nelson \& Connor, 2009), Ephemeroptera (Kelly-Quinn \& Regan, 2012), Hymenoptera (Fitzpatrick et al., 2007), Lepidoptera (Allen et al., 2016; Regan et al., 2010), Odonata (Nelson, Ronayne \& Thompson, 2011) and Plecoptera (Feeley et al., 2020), and mammals (Marnell et al., 2019). The full dataset of policy lists, European IUCN red listing, and UK and Ireland level IUCN-style assessments is provided as supplementary material (see Table S1). 


\subsection{Statistical Analysis}

A workflow of how the data collected was applied to the analysis can be found as supplementary material (Figure S1). Using the data from Bernard (2011), we calculated an expected number of species that would be covered in each policy if the policy reflected the richness of each insect order in the UK and Ireland. The data from Bernard (2011) could not be parsed by country, so this approach assumed that the UK and Ireland have relatively similar entomofauna communities in terms of the proportions of each insect order. This assumption can introduce biases in the accuracy of our assessments of taxonomic coverage for the policies in Northern Ireland. Nevertheless, given the available data, our approach still provides a reasonable baseline of the diversity of insect orders listed by policies in Ireland and Northern Ireland. We calculated the proportion of the 15 most speciose insect orders (grouping the remaining as 'other') composing the entomofauna (Table S2), and calculated the expected count for each order on each policy by:

\section{Expected No. Species $=($ Order's Proportion of Entomofauna $\times$ No. Insect Species on List $)$}

This provided us with a null hypothesis from which statistical inferences could be conducted. This approach assumes that species across all orders face equal extinction risk, which may not be true but nevertheless allowed us to test how the policies perform in their representativity of the entomofauna and detect any biases in policies (e.g., orders being overrepresented, relative to their richness in the entomofauna). To test for differences between the expected and observed values, a Pearson's Chi-Squared test with Monte-Carlo simulated p-value (based on 2000 replicates) was used. This test was run for the Wildlife and Countryside Act 1981, Wildlife Order 1985, and the priority biodiversity lists for each country within the UK. The Northern Irish Conservation Regulations 1995, and the Irish Wildlife Act 1976 could not be assessed for taxonomic bias because they list zero insect species. Statistical significance does not imply conservation efforts should be partitioned differently, nor that the efforts are unfair or ineffective. Rather, statistical significance suggests that the protection of a particular order is above (or below) of that expected given the representativity of the order in the entomofauna.

Next, we analysed the red list category of the insect species listed on the priority biodiversity lists of each UK country, using assessments of extinction risk carried out in the UK (for Scotland, England, and Wales) and Ireland (for Northern Ireland). To do so, we extracted the species that were listed as threatened with extinction (vulnerable, endangered, or critically endangered) from the assessments for the UK and Ireland, for each group of insects. The number of threatened species was plotted against the number from that subset of species which are listed as a priority species in Scotland, England, Wales, and Northern Ireland, with a diagonal (slope $=1$ ) line for reference. Data points along the line indicate that the number of threatened species and the number of threatened species prioritised within the order are equivalent. Data points falling below the diagonal line show that there are more species threatened with extinction that remain unlisted by the policies. These plots allowed us to determine if the priorities on these lists reflected the species most urgently at risk of extinction within each insect group. Lastly, we benchmarked policy coverage by contrasting the coverage of conservation policies for insects vs. mammals using the Wildlife and Countryside Act 1981, Wildlife Order 1985 \& Conservation Regulations 1995, and the Wildlife Act 1976. Using the methodology as above, the number of regional red list species per mammalian or insect order was plotted against the number of those species protected by each policy. We plotted just those species identified as Vulnerable, Endangered, or Critically Endangered on the regional red list, which excluded nearly all mammals from the analysis. We then plotted all mammals and insects found in the UK and Ireland from the European IUCN Red List protected by these policies, irrespective of extinction risk status. This allowed us to determine if there was an influence of the European IUCN Red List upon mammalian protection status in the UK and Ireland, in the absence of an immediate extinction risk. We hypothesised that the Wildlife and Countryside Act 1981, Wildlife Order 1985 \& Conservation Regulations 1995, and Wildlife Act 1976 may be biased toward mammals, given that there are existing biases toward mammals (and vertebrates more generally) in EU-level policies, conservation funding, and public attention (Davies et al., 2018; Donaldson et al., 2017; Mammola et al., 2020). All statistical analyses and plotting were carried out using $\mathrm{R}$ version 3.6.2 (R Core Team, 2019) 
and packages 'ggplot2' (Wickham, 2016), 'ggrepel' (Slowikowski, 2020), and 'ggpubr' (Kassambara, 2020).

\section{Results}

3.1 Taxonomic biases favour the protection of Lepidoptera over other insect orders

There were marked differences between the orders listed by the UK policies. The priority lists were much more taxonomically diverse than the Wildlife and Countryside Act 1981 and the Wildlife Order 1985, which predominantly listed Lepidoptera (butterflies and moths), Odonata (dragonflies), Coleoptera (beetles), Orthoptera (grasshoppers), and Hemiptera (true bugs) (Fig 2). These biases reflect previously identified biases in EU policies to the detriment of other diverse insect orders, such as Hymenoptera and Diptera (Cardoso et al., 2012; Leandro et al., 2017). The Wildlife and Countryside Act 1981 (Fig 2) showed an overrepresentation of Lepidoptera $(N=35)$, underrepresentation of Diptera (true flies) $(N=0)$, Hymenoptera (bees, ants, and wasps) $(N=0)$, and Hemiptera $(N=1)$, and exact representation of Coleoptera $(N=8)\left(\chi^{2}: 49.29\right.$, p: 0.022$)$. The Wildlife Order 1985 (Fig 2) was limited to exclusively Lepidoptera $(N=8)$ and Odonata $(N=1)$ species, however, no significant bias was detected $\left(\chi^{2}: 4.99, \mathrm{p}: 0.554\right)$. The lack of significant bias detected might be attributed to the small sample size obtained from the Wildlife Order 1985, comprising just nine insect species. England priority species (Fig 2) showed an overrepresentation of Lepidoptera $(N=165)$, and Coleoptera $(N=75)$ and an underrepresentation of Hymenoptera $(N=31)$, Hemiptera $(N=10)$, and Diptera $(N=28),\left(\chi^{2}: 128, \mathrm{p}: 0.0005\right)$. This pattern of representation was also observed in the Scotland priority species (Fig $2, \chi^{2}: 75.09, p: 0.049$ ), and the Northern Ireland priority species (Fig 2, $\chi^{2}: 47.56$, p: 0.032). No statistically significant difference in representation was detected for the Wales priority species $\left(\chi^{2}: 54.10, p: 0.169\right)$. However, the Welsh list showed an overrepresentation of Lepidoptera $(N=115)$, and an underrepresentation of all other groups (Fig 2). Overall, the number of Lepidopteran species was higher than one would expect based on the representativity of this order (10.7\%) whilst Hymenoptera, Diptera, and Hemiptera were underrepresented relative to their representativity (29.1\% for Hymenoptera, and Diptera and $7.6 \%$ for Hemiptera) in the entomofauna.

In addition to the 5 most speciose orders, each country's biodiversity lists also include 'Other Taxa' to incorporate a small number of species from Ephemeroptera (mayflies) (England $N=2$; Scotland $N=1$; Wales $N=2$ ), Odonata (England $N=2$; Scotland $N=3$; Wales $N=1$, Northern Ireland $N=1$ ), Orthoptera (England $N=4$; Scotland $N=2$; Wales $N=1$ ), Neuroptera (lacewings) (Scotland $N=2$ ), Plecoptera (stoneflies) (England $N=1$; Scotland $N=1$; Wales $N=3$ ) and Trichoptera (caddisflies) (England $N=4$; Scotland $N$ $=1$; Wales $N=1$ ). Absent from any policy were Rhapidioptera (snakeflies), Megaloptera (alderflies) and Mecoptera (scorpionflies). Other orders are also absent including earwigs, thrips, booklice, and fleas from the orders Phthiraptera, Dermaptera, Psocoptera, Thysanoptera, and Siphonaptera, which are likely absent because they are often considered pests. The exception to this was the Scottish biodiversity list which included a species of Dermaptera (Labia minor), which is a detritivore at the edge of its range in Scotland (Burton and Burton, 2002; NBN Atlas, 2021) and a species of Siphonaptera (Ceratophyllus (Emmareus ) fionnus ), which is endemic on the Isle of Rùm (Kwak et al., 2019).

\subsection{Priority lists fail to prioritise some endangered insects}

The taxonomic biases observed above (Fig 2) could be explained by overrepresented orders having higher numbers of threatened species in the UK and Ireland than other orders do, therefore requiring this level of prioritisation. The UK priority biodiversity lists were observed to list a number of insects (England $N$ $=322$, Scotland $N=344$, Wales $N=167$, Northern Ireland $N=143$ ) that were 'of principal importance for conservation', a less stringent but nevertheless important obligation that the national-level species protection policies described above do not have. We found that many vulnerable, endangered, or critically endangered butterflies were listed as a priority species, while for other groups, many threatened species were not prioritised (Fig 3a-c). For instance, in England (Fig 3a), 89.5\% of butterflies threatened with extinction were listed as a priority whereas $21.5 \%$ of threatened Coleoptera, $20.3 \%$ of threatened Hymenoptera, $20.6 \%$ of threatened moths, and $14.6 \%$ of threatened Diptera were listed. A similar trend was observed in Wales (Fig 3b), with $63.2 \%$ of threatened butterflies listed, in contrast to just of $7.3 \%$ threatened Coleoptera, $3.4 \%$ of threatened 
Hymenoptera, $3.2 \%$ of threatened moths, and $2.4 \%$ of threatened Diptera. Scotland did not show this trend, instead demonstrating low numbers of threatened species from every group listed as a priority (Fig 3c), including $26.3 \%$ of threatened butterflies, $9.6 \%$ of threatened Coleoptera, $5 \%$ of threatened Hymenoptera, $0 \%$ of threatened moths, and $17 \%$ of threatened Diptera. In Northern Ireland, $66.7 \%$ of butterflies threatened with extinction on the Irish red list were a priority species, as well as $60 \%$ of threatened bees, and $51.3 \%$ of threatened aquatic Coleoptera, $14 \%$ of threatened moths, and $0 \%$ of threatened Ephemeroptera and Plecoptera. Thus, Northern Ireland demonstrated a higher representation of some threatened non-Lepidopteran orders than the priority lists in Scotland, England, and Wales (Fig 3d). Overall, though, these findings suggest that (1) the taxonomic biases towards Lepidopterans are not necessarily due to higher number of species being classified as endangered, and (2) that many endangered insect species remain overlooked in priority lists.

3.3 Protective policies largely protect mammals, but only few insects

The biases and gaps described above can emerge if policies themselves are biased across their entire scope. If this is the case, then we would expect to see similar biases and trends for other groups. To investigate this, we compared the policy coverage for insect versus mammals at risk of extinction, firstly using the regional red lists for Great Britain and Ireland (Fig 4a-c). Of the 12 species of mammal at risk of extinction in Great Britain, 9 were protected (75\%) by the Wildlife and Countryside Act 1981, versus just $0.07 \%$ of the 404 at risk insects in Great Britain (Fig 4a). Interestingly, just a single species of mammal is endangered in Ireland (Rattus rattus), which is protected by neither the Wildlife Order 1985 and Conservation Regulations 1995, nor the Wildlife Act 1976 (Fig 4b-c). The former protects 4 (0.03\%) of Ireland's 131 at risk insects (Fig 4b), while the Wildlife Act 1976 protects no insect species (Fig 4c). Interestingly, when we expanded the scope, we found that out of the 81 UK mammal species on the IUCN European red list, 49 (61\%) were covered by the Wildlife and Countryside Act 1981. In fact, all (100\%) species of Chiroptera (bats), 90\% of Certartiodactyla (whales and dolphins) and 67\% of Lagomorpha (rabbits and hares) present on the IUCN European red list were protected by this policy (Fig 5a). Conversely, from the 548 insect species from the IUCN European red list in the UK, only $30(\sim 5.4 \%)$ were listed by the Wildlife and Countryside Act 1981. A similar pattern was identified in Northern Ireland, with the Wildlife Order 1985 and Conservation Regulations 1995 together protecting $42(84 \%)$ of the 50 Irish mammals on the IUCN European red list but covering just $8(\sim 3.8 \%)$ of the 211 Irish IUCN European red list insect species (Fig 5b). Likewise, in Ireland, of the 50 species of mammal from the IUCN European red list found in Ireland, 38 (76\%) were covered by Wildlife Act 1976 (Fig 5c) including 100\% of Eulipotyphla (hedgehogs and shrews), $88 \%$ of Certartiodactyla and $83 \%$ of Chiroptera. Strikingly, the Wildlife Act 1976 did not protect a single insect species.

\section{Discussion}

In this study, we showed that (1) overall there is an overrepresentation of Lepidoptera, and an underrepresentation of Hemiptera, Hymenoptera, and Diptera in UK and Irish policies, (2) this bias does not reflect a disproportionate listing of endangered species, given that many endangered species have been overlooked and that (3) policy coverage is not consistent across taxa when comparing insects versus mammals, suggesting that potential discrimination between the scope of policies in the protection of vertebrate versus invertebrate biodiversity. Together, these findings suggest that without effective policy to guide conservation efforts, insect biodiversity is likely to decline at rates that match, or even exceed those of vertebrate species (Dirzo et al., 2014; Thomas et al., 2004; Thomas and Morris, 1997). Such declines could jeopardise key functions in the ecosystem, with insects playing a role in pest control (Feener and Brown, 1997; Shaw and Hochberg, 2001), decomposition (Beynon et al., 2015; Seibold et al., 2021), carbon sequestration (Metcalfe et al., 2014; Orians et al., 2011), and pollination of flowering plants (Garibaldi et al., 2013; IPBES, 2016). This is in addition to the role of insects as a food source (Costa-Neto and Dunkel, 2016; Looy et al., 2014; Ramos Elorduy, 2005), numerous contributions to human culture (Duffus et al., 2021), and other unconventional ecosystem services (Morimoto, 2020). A reduction in these functions could have major impacts upon society, for instance by reducing food security, with 5-8\% of the world's most nutritionally important crops dependent on animal pollination (Gallai et al., 2009; IPBES, 2016).

We found a relative overrepresentation of Lepidoptera and underrepresentation of other insect orders in our 
analysis of UK and Irish policies. This can have long-term implications on ecosystem functions provided that Hymenoptera and Diptera are, along with Lepidoptera, major pollinators (Garibaldi et al., 2013; Orford et al., 2015; Ssymank et al., 2008; Winfree et al., 2007). Moreover, many Hymenopterans and Dipterans are parasitoids that can play crucial roles in the biological control of other insect pests and ensure high food security with minimal economic burden of pests (Feener and Brown, 1997; Shaw and Hochberg, 2001). Several reasons could result in policy biases towards Lepidopterans. Firstly, there could simply have been more Lepidopterans at higher extinction risk than other orders, or at least a perception that Lepidopterans are more vulnerable relative to other orders, prompting immediate conservation actions which would be translated into biases towards Lepidopterans in policies. This is possible because in Europe, butterflies are a small but well-monitored group (Swaay et al., 2008), with a large suite of data to support their conservation, while for other insect groups, conservation is impeded by data availability (Cardoso et al., 2011b). Therefore, if (or when) more data for other groups become available, the biases observed here could disappear as more species from other orders are known to be at risk and therefore, are incorporated into the policies. This is possible given that all of the policies studied here are regularly reviewed and updated. However, in the priority biodiversity lists analysed here, endangered Lepidopterans (butterfly only) species were better represented than other endangered insect species of other orders, suggesting that the taxonomic biases found in our study are not simply due to data and risk status of insect species. Biases toward Lepidoptera and other large flying insects (e.g., Odonates) have previously been identified in the Bern Convention and EU Habitats Directive (Cardoso, 2012; Leandro et al., 2017). Additionally, there are biases in the IUCN red listing process, which have the potential to influence policies. The subjective nature of red listing, and the dependence upon specialist knowledge and extensive data has the potential to exclude insect species from red lists, or misclassify their extinction risk (Cardoso et al., 2011a; Regnier et al., 2009; Regnier et al., 2015; Fox et al., 2019). For example, the assessment process for red lists requires evidence in the form of long-term population monitoring. For insects, there are just 166 datasets globally, that span 10 years or more (van Klink et al., 2020), presenting a shortfall in data. Given our usage of these lists in our methodologies, these biases could be introduced into our analysis. However, given that conservation policies make extensive use of these lists, any bias in the red lists will likely be inbuilt into policies, thus our methodology is still the most appropriate approach to the research question. These different biases in higher-level directives and red listing processes suggest that biases in the UK policies can to some extent reflect a "top-down" bias, or a bias reflecting the favourable attitude of the public toward Lepidoptera versus other insect groups (Sumner et al., 2018).

Another potential way in which taxonomic biases could occur in the policies is due to the use of Lepidopterans as indicators of habitat quality or as umbrella species for the conservation of insects more generally (Hopkins and Thacker, 2016; Launer and Murphy, 1994; Spitzer et al., 2009). To date, there is insufficient evidence to suggest the effectiveness of a sole group to be relied upon as a metric of site diversity, and often Hemipteran species have the strongest correlation to site diversity (Gaspara et al., 2010; Obrist and Martin, 1998). Moreover, conservation focused on a single or few insect groups may overlook - or even harm - the conservation of other insects with complex life-histories. For example, parasitoid wasps have delicate life cycles that differ from the majority of Lepidopterans as these parasitoid species depend on host availability and habitat quality that a focus on Lepidopteran conservation cannot incorporate (Kendall and Ward, 2016; Shaw, 2006). Likewise, insects with aquatic larval stages (e.g., Odonata and Ephemeroptera) have additional requirements pertaining to the freshwater environment that can be overlooked if the conservation focuses on terrestrial Lepidopterans as an umbrella group (Corkum, 1989; Hofmann and Mason, 2005). Importantly, some of these groups with complex life histories are almost entirely absent from policies and utilising Lepidopterans as umbrella species may overlook those requirements, making such a bias potentially detrimental to insect conservation more generally. This is not to say that Lepidoptera should not be the focus of conservation efforts but expanding this focus to other species-rich orders such as Hymenoptera and Diptera may generate large scale and long-term benefits for biodiversity conservation, by conserving the functional roles played by species in these orders.

We found the biases and gaps across policies for insect conservation are less accentuated for mammals. In 
fact, most of the mammals protected by these policies are of least concern on the regional red list, indicating that the high level of protection afforded to mammal species is not due to their current extinction risks in the UK and Ireland. Instead, this level of protection may be because of an observational bias, in which larger, more conspicuous mammals are more readily studied than smaller animals (including invertebrates), and hold additional value in their relationships to humans, creating anthropocentric priorities (Ladle et al., 2019; Frynta et al., 2013; Donaldson et al., 2016). This assigned value to mammals has resulted in policies like those assessed here, which were tailored to the conservation of larger vertebrate species by reducing direct human pressures (i.e., hunting). This is not a pressure which endangers insects, except from some Lepidopterans, which were originally listed on policies such as the Wildlife and Countryside Act 1981 in order to legislate the trade of endangered butterflies (Nature Conservancy Council, 1986). For many insects, climatic and land-use changes are primary drivers of decline (Cardoso et al., 2020; Habel et al., 2019; Samways et al., 2020). Despite this, vulnerability to extinction as a consequence of such change is not sufficient reason for listing species on these stringent policies (JNCC, 2014), creating challenges in presenting a rationale for listing insect species. One way to circumvent this limitation is through a series of steps to ensure that policies - or some sort of legal support - exist and target insect species. We provide here a series of recommendations to further bring the conservation of insect biodiversity into the scope of policies in the UK and Ireland, based on our findings and the literature.

1. Create priority biodiversity lists by recognising the ecological role of species (Martín et al., 2010), and developing appropriate criteria for assessing the extinction risk of insects (Cardoso et al., 2011a; Fox et al., 2019), to avoid taxonomically biased listings. The use of life history traits as a proxy for extinction risk when selecting priority species could also be considered in the absence of long-term, standardised population monitoring (Bowler et al., 2017; Chichorro et al., 2019).

2. Incorporate requirements for standardised data collection and population monitoring for priority species across the diversity of insect orders into conservation action. This echoes calls to feature further standardised data collection into Biodiversity Action Plans (Sutherland et al., 2004), particularly for data that will further our knowledge of the efficacy of conservation actions and provide evidence for policy interventions.

3. Tackle the main drivers of insect declines (Cardoso et al., 2020) explicitly in policies. For instance, by prioritising habitat connectivity within policies (Sutherland et al., 2010) such as in agri-environmental policies and planning policies, in order to create resilient, well-connected ecosystems. This is already being pioneered by the Buglife project, which aims to create 'super highways' across the UK, connecting insect habitats (Buglife, 2021). In addition, strict control of pesticides (Goulson, 2013; Sánchez-Bayo, 2014; Sluijs et al., 2013), and invasive species (Tallamy et al., 2021) would be of benefit to insect biodiversity.

4. Expansion of the current strategy of national plans for the conservation of pollinators in the UK and Ireland to other functional insect groups (e.g., decomposers or parasitoids'), to ensure both the conservation of insect species and the continuity of ecosystem services.

\section{Conclusions}

This study highlights gaps in the policies of the UK and Ireland that can influence the effectiveness of policies to protect insect biodiversity and consequently, the ecosystem services insects provide. Moving forwards, political recognition of the need to establish long-term, standardised, population monitoring for a diversity of orders will allow for the setting of priorities based on extinction risk, thereby targeting the most endangered species. Such monitoring schemes can be highly cost-effective data collection approaches, as evidenced by the UK Pollinator Monitoring Scheme, which has detected the population trend of 377 pollinator species (Breeze et al., 2021; Carvell, 2020). While this study examined species-specific conservation policies, there is also a gap in our knowledge of how effective other environmentally relevant policies are for insect conservation. This includes different protected area designations, pesticide regulations, and agricultural policies. Such policies have the scope to tackle the key drivers of insect declines, and thus, will be critical to maintain the habitats in which insects exist. Public engagement and NGO initiatives will also play a role in policy change, while citizen science initiatives will provide invaluable cost-effective baseline monitoring data to underpin 
the inclusion or exclusion of species in priority species listing based on their conservation status.

\section{Data accessibility statement}

The data used in this study are available as electronic supplementary materials.

\section{Acknowledgements}

We would like to acknowledge Dr Jeff Ollerton and the two anonymous reviewers for their helpful comments on the original version of this manuscript.

\section{Bibliography}

Aizen, M.A., Garibaldi, L.A., Cunningham, S.A., Klein, A.M., 2009. How much does agriculture depend on pollinators? Lessons from long-term trends in crop production. Ann. Bot. 103, 1579-1588. https://doi.org/10.1093/aob/mcp076

Allen, D., O'Donnell, M., Nelson, B., Tyner, A., Bond, K.G.M., Bryant, T., Crory, A., Mellon, C., O’Boyle, J., O’Donnell, E., Rolston, T., Sheppard, R., Strickland, P., Fitzpatrick, U., \& Regan, E., 2016. Ireland Red List No.9: Macro-moths (Lepidoptera). Natl. Park. Wildl. Serv. Dep. Arts, Herit. Gaeltacht, Dublin, Irel.

Balfour, N.J., Ollerton, J., Castellanos, M.C., Ratnieks, F.L.W., 2018. British phenological records indicate high diversity and extinction rates among late-summer-flying pollinators. Biol. Conserv. 222, 278-283. https://doi.org/10.1016/j.biocon.2018.04.028

Barnard, P.C., 2011. The Royal Entomological Society Book of British Insects. Wiley-Blackwell, Oxford, UK. https://doi.org/10.1002/9781444344981

Batavia, C., Nelson, M.P., 2017. For goodness sake! What is intrinsic value and why should we care? Biol. Conserv. 209, 366-376. https://doi.org/10.1016/j.biocon.2017.03.003

Bell, J.R., Blumgart, D., Shortall, C.R., 2020. Are insects declining and at what rate? An analysis of standardised, systematic catches of aphid and moth abundances across Great Britain. Insect Conserv. Divers. 13, 115-126. https://doi.org/10.1111/icad.12412

Beynon, S.A., Wainwright, W.A., Christie, M., 2015. The application of an ecosystem services framework to estimate the economic value of dung beetles to the U.K. cattle industry. Ecol. Entomol. 40, 124-135. https://doi.org/10.1111/een.12240

Bombelli, P., Howe, C.J., Bertocchini, F., 2017. Polyethylene bio-degradation by caterpillars of the wax moth Galleria mellonella. Curr. Biol. 27, 292-293. https://doi.org/10.1016/j.cub.2017.02.060

Bowler, D.E., Haase, P., Hof, C., Kröncke, I., Baert, L., Dekoninck, W., Domisch, S., Hendrickx, F., Hickler, T., Neumann, H., O'Hara, R.B., Sell, A.F., Sonnewald, M., Stoll, S., Türkay, M., van Klink, R., Schweiger, O., Vermeulen, R., Böhning-Gaese, K., 2017. Cross-taxa generalities in the relationship between population abundance and ambient temperatures. Proc. R. Soc. B Biol. Sci. 284, 20170870. https://doi.org/10.1098/rspb.2017.0870

Breeze, T.D., Bailey, A.P., Balcombe, K.G., Brereton, T., Comont, R., Edwards, M., Garratt, M.P., Harvey, M., Hawes, C., Isaac, N., Jitlal, M., Jones, C.M., Kunin, W.E., Lee, P., Morris, R.K.A., Musgrove, A., O'Connor, R.S., Peyton, J., Potts, S.G., Roberts, S.P.M., Roy, D.B., Roy, H.E., Tang, C.Q., Vanbergen, A.J., Carvell, C., 2021. Pollinator monitoring more than pays for itself. J. Appl. Ecol. 58, 44-57. https://doi.org/10.1111/1365-2664.13755

Brereton, T., Roy, D.B., Middlebrook, I., Botham, M., Warren, M., 2011. The development of butterfly indicators in the United Kingdom and assessments in 2010. J. Insect Conserv. 15, 139-151. https://doi.org/10.1007/s10841-010-9333-z

Brooks, D.R., Bater, J.E., Clark, S.J., Monteith, D.T., Andrews, C., Corbett, S.J., Beaumont, D.A., Chapman, J.W., 2012. Large carabid beetle declines in a United Kingdom monitoring network increases evidence 
for a widespread loss in insect biodiversity. J. Appl. Ecol. 49, 1009-1019. https://doi.org/10.1111/j.13652664.2012.02194.x

Brown, P., Roy, H., 2015. Reflections on the long-term assessment of ladybird (Coleoptera: Coccinellidae) populations in the Czech Republic and the United Kingdom. Acta Soc. Zool. Bohemicae 79, 19-27.

Buglife, 2021. B-Lines [WWW Document]. URL https://www.buglife.org.uk/our-work/b-lines/ (accessed 11.14.21).

Burton, M., Burton, R., 2002. International Wildlife Encyclopedia, Volume 10, 3rd ed. Marshall Cavendish.

Cardoso, P., 2012. Habitats Directive species lists: Urgent need of revision. Insect Conserv. Divers. 5, 169-174. https://doi.org/10.1111/j.1752-4598.2011.00140.x

Cardoso, P., Barton, P.S., Birkhofer, K., Chichorro, F., Deacon, C., Fartmann, T., Fukushima, C.S., Gaigher, R., Habel, J.C., Hallmann, C.A., Hill, M.J., Hochkirch, A., Kwak, M.L., Mammola, S., Ari Noriega, J., Orfinger, A.B., Pedraza, F., Pryke, J.S., Roque, F.O., Settele, J., Simaika, J.P., Stork, N.E., Suhling, F., Vorster, C., Samways, M.J., 2020. Scientists' warning to humanity on insect extinctions. Biol. Conserv. 242, 108427. https://doi.org/10.1016/j.biocon.2020.108426

Cardoso, P., Borges, P.A.V., Triantis, K.A., Ferrández, M.A., Martín, J.L., 2011a. Adapting the IUCN Red List criteria for invertebrates. Biol. Conserv. 144, 2432-2440. https://doi.org/10.1016/j.biocon.2011.06.020

Cardoso, P., Erwin, T.L., Borges, P.A.V., New, T.R., 2011b. The seven impediments in invertebrate conservation and how to overcome them. Biol. Conserv. 144, 2647-2655. https://doi.org/10.1016/j.biocon.2011.07.024

Carvell, C., 2020. UK Pollinator Monitoring and Research Partnership (PMRP): Progress Report October 2020.

Chichorro, F., Juslén, A., Cardoso, P., 2019. A review of the relation between species traits and extinction risk. Biol. Conserv. 237, 220-229. https://doi.org/10.1016/j.biocon.2019.07.001

Clavel, J., Julliard, R., Devictor, V., 2011. Worldwide decline of specialist species: toward a global functional homogenization? Front. Ecol. Environ. 9, 222-228. https://doi.org/10.1890/080216

Cole, L.J., Kleijn, D., Dicks, L. V., Stout, J.C., Potts, S.G., Albrecht, M., Balzan, M. V., Bartomeus, I., Bebeli, P.J., Bevk, D., Biesmeijer, J.C., Chlebo, R., Dautartè, A., Emmanouil, N., Hartfield, C., Holland, J.M., Holzschuh, A., Knoben, N.T.J., Kovács-Hostyanszki, A., Mandelik, Y., Panou, H., Paxton, R.J., Petanidou, T., Pinheiro de Carvalho, M.A.A., Rundlof, M., Sarthou, J., Stavrinides, M.C., Suso, M.J., Szentgyorgyi, H., Vaissiere, B.E., Varnava, A., Vila, M., Zemeckis, R., Scheper, J., 2020. A critical analysis of the potential for EU Common Agricultural Policy measures to support wild pollinators on farmland. J. Appl. Ecol. 57, 681-694. https://doi.org/10.1111/1365-2664.13572

Corkum, L.D., 1989. Habitat characterization of the morphologically similar mayfly larvae, Caenis and Tricorythodes (Ephemeroptera). Hydrobiologia 179, 103-109. https://doi.org/10.1007/BF00007597

Costa-Neto, E.M., Dunkel, F.V., 2016. Insects as Food: History, Culture, and Modern Use around the World, in: Insects as Sustainable Food Ingredients. Elsevier, pp. 29-60. https://doi.org/10.1016/B978-0$12-802856-8.00002-8$

Council of Europe, 2020. The Bern Convention - Convention on the Conservation of European Wildlife and Natural Habitats [WWW Document]. URL https://www.coe.int/en/web/bern-convention (accessed 9.12.20).

Cullen, E., $2017 . \quad$ Insect Pollinators and Policy. CUSPE Commun. https://doi.org/https://doi.org/10.17863/CAM.25634

DAERA, 2010. List of Northern Irelaand Priority Species - Department of Agriculture, Environment and 
Rural Affairs [WWW Document]. URL https://www.daera-ni.gov.uk/publications/list-northern-irelandpriority-species (accessed 5.15.21).

Daskalova, G.N., Phillimore, A.B., Myers-Smith, I.H., 2021. Accounting for year effects and sampling error in temporal analyses of invertebrate population and biodiversity change: a comment on Seibold et al . 2019. Insect Conserv. Divers. 14, 149-154. https://doi.org/10.1111/icad.12468

Davies, T., Cowley, A., Bennie, J., Leyshon, C., Inger, R., Carter, H., Robinson, B., Duffy, J., Casalegno, S., Lambert, G., Gaston, K., 2018. Popular interest in vertebrates does not reflect extinction risk and is associated with bias in conservation investment. PLoS One 13, e0203694. https://doi.org/10.1371/journal.pone.0203694

Dennis, E.B., Brereton, * T M, Morgan, ${ }^{*}$ B J T, Fox, ${ }^{*}$ R, Shortall, * C R, Prescott, ${ }^{*}$ T, Foster, * S, 2019. Trends and indicators for quantifying moth abundance and occupancy in Scotland. J. Insect Conserv. 23, 369-380. https://doi.org/10.1007/s10841-019-00135-z

Didham, R.K., Basset, Y., Collins, C.M., Leather, S.R., Littlewood, N.A., Menz, M.H.M., Muller, J., Packer, L., Saunders, M.E., Schonrogge, K., Stewart, A.J.A., Yanoviak, S.P., Hassall, C., 2020. Interpreting insect declines: seven challenges and a way forward. Insect Conserv. Divers. 13, 103-114. https://doi.org/10.1111/icad.12408

Dirzo, R., Young, H.S., Galetti, M., Ceballos, G., Isaac, N.J.B., Collen, B., 2014. Defaunation in the Anthropocene. Science (80-. ). 345, 401-406. https://doi.org/10.1126/science.1251817

Donaldson, M.R., Burnett, N.J., Braun, D.C., Suski, C.D., Hinch, S.G., Cooke, S.J., Kerr, J.T., 2017. Taxonomic bias and international biodiversity conservation research. FACETS 1, 105-113. https://doi.org/10.1139/facets-2016-0011

Duffus, N.E., Christie, C.R., Morimoto, J., 2021. Insect Cultural Services: How Insects Have Changed Our Lives and How Can We Do Better for Them. Insects 12, 377. https://doi.org/10.3390/insects12050377

European Commission, 2020. The Habitats Directive [WWW Document]. URL https://ec.europa.eu/environment/nature/legislation/habitatsdirective/index_en.htm (accessed 9.12.20).

Feeley, H.B., Baars, J-R., Kelly-Quinn, M. \& Nelson, B., 2020. Ireland Red List No.13: Stoneflies (Plecoptera). Natl. Park. Wildl. Serv. Dep. Cult. Herit. Gaeltacht, Dublin, Ireland.

Feener, D.H., Brown, B. V., 1997. Diptera as parasitoids. Annu. Rev. Entomol. 42, 73-97. https://doi.org/10.1146/annurev.ento.42.1.73

Fitzpatrick, U., Murray, T.E., Paxton, R.J., Brown, M.J.F., 2007. Building on IUCN regional red lists to produce lists of species of conservation priority: A model with Irish bees. Conserv. Biol. 21, 1324-1332. https://doi.org/10.1111/j.1523-1739.2007.00782.x

Forister, M.L., Pelton, E.M., Black, S.H., 2019. Declines in insect abundance and diversity: We know enough to act now. Conserv. Sci. Pract. 1, e80. https://doi.org/10.1111/csp2.80

Foster, G. N., Nelson, B. H. \& O Connor, A., 2009. Ireland Red List No. 1 - Water Beetles. Natl. Park. Wildl. Serv. Dep. Environ. Herit. Local Gov. Dublin, Ireland.

Fox, R., Harrower, C.A., Bell, J.R., Shortall, C.R., Middlebrook, I., Wilson, R.J., 2019. Insect population trends and the IUCN Red List process. J. Insect Conserv. 23, 269-278. https://doi.org/10.1007/s10841-0180117-1Frynta, D., Šimková, O., Lišková, S., Landová, E., 2013. Mammalian Collection on Noah's Ark: The Effects of Beauty, Brain and Body Size. PLoS One 8, e63110. https://doi.org/10.1371/journal.pone.0063110

Gardiner, T., Didham, R.K., 2020. Glowing, glowing, gone? Monitoring long-term trends in glow-worm numbers in south-east England. Insect Conserv. Divers. 13, 162-174. https://doi.org/10.1111/icad.12407 
Garibaldi, L.A., Steffan-Dewenter, I., Winfree, R., Aizen, M.A., Bommarco, R., Cunningham, S.A., Kremen, C., Carvalheiro, L.G., Harder, L.D., Afik, O., Bartomeus, I., Benjamin, F., Boreux, V., Cariveau, D., Chacoff, N.P., Dudenhoffer, J.H., Freitas, B.M., Ghazoul, J., Greenleaf, S., Hipolito, J., Holzschuh, A., Howlett, B., Isaacs, R., Javorek, S.K., Kennedy, C.M., Krewenka, K.M., Krishnan, S., Mandelik, Y., Mayfield, M.M., Motzke, I., Munyuli, T., Nault, B.A., Otieno, M., Petersen, J., Pisanty, G., Potts, S.G., Rader, R., Ricketts, T.H., Rundlof, M., Seymour, C.L., Schuepp, C., Szentgyorgyi, H., Taki, H., Tscharntke, T., Vergara, C.H., Viana, B.F., Wanger, T.C., Westphal, C., Williams, N., Klein, A.M., 2013. Wild pollinators enhance fruit set of crops regardless of honey bee abundance. Science (80-. ). 640, 1608-1611. https://doi.org/10.1126/science.1230200

Gaspara, C., J.Gaston, K., A.V.Borges, P., 2010. Arthropods as surrogates of diversity at different spatial scales. Biol. Conserv. 143, 1287-1294. https://doi.org/10.1016/j.biocon.2010.03.007

Goulson, D., 2013. REVIEW: An overview of the environmental risks posed by neonicotinoid insecticides. J. Appl. Ecol. 50, 977-987. https://doi.org/10.1111/1365-2664.12111

Habel, J.C., Samways, M.J., Schmitt, T., 2019. Mitigating the precipitous decline of terrestrial European insects: Requirements for a new strategy. Biodivers. Conserv. 28, 1343-1360. https://doi.org/10.1007/s10531019-01741-8

Hall, D.M., Steiner, R., 2019. Insect pollinator conservation policy innovations at subnational levels: Lessons for lawmakers. Environ. Sci. Policy 93, 118-128. https://doi.org/10.1016/j.envsci.2018.12.026

Hofmann, T.A., Mason, C.F., 2005. Habitat characteristics and the distribution of Odonata in a lowland river catchment in eastern England. Hydrobiologia 539, 137-147. https://doi.org/10.1007/s10750-004-3916-1

Hopkins, G.W., Thacker, J.I., 2016. Protected species and development control: the merits of widespread invertebrate species in the European Habitats Directive and UK legislation. Insect Conserv. Divers. 9, 259-267. https://doi.org/10.1111/icad.12171

Irish Statute Book, 2021. Wildlife Act 1976 [WWW Document]. URL http://www.irishstatutebook.ie/eli/1976/act/39/enacted/en/html\#zza39y1976 (accessed 5.20.21).

IPBES, 2016. The assessment report of the Intergovernmental Science-Policy Platform on Biodiversity and Ecosystem Services on pollinators, pollination and food production. Secretariat of the Intergovernmental Science-Policy Platform on Biodiversity and Ecosystem Services, Bonn. https://doi.org/https://doi.org/10.5281/zenodo.3402856

IUCN, 2021. The IUCN Red List of Threatened Species Version 2021-1 [WWW Document]. URL https://www.iucnredlist.org/ (accessed 5.15.21).

JNCC, 2020. Conservation Designations for UK Taxa [WWW Document]. URL https://hub.jncc.gov.uk/assets/478f7160-967b-4366-acdf-8941fd33850b (accessed 9.20.20).

JNCC, 2014. Sixth Quinquennial Review of Schedules 5 and 8 of the Wildlife and Countryside Act 1981: Report and Recommendations from the Joint Nature Conservation Committee.

Kassambara, A., 2020. ggpubr: "ggplot2" Based Publication Ready Plots. R package version 0.40.

Kelly-Quinn, M. \& Regan, E.C., 2013. Ireland Red List No.7: Mayflies (Ephemeroptera). Natl. Park. Wildl. Serv. Dep. Arts, Herit. Gaeltacht, Dublin, Ireland.

Kendall, L.K., Ward, D.F., 2016. Habitat determinants of the taxonomic and functional diversity of parasitoid wasps. Biodivers. Conserv. 25, 1955-1972. https://doi.org/10.1007/s10531-016-1174-y

Klein, A.M., Vaissiere, B.E., Cane, J.H., Steffan-Dewenter, I., Cunningham, S.A., Kremen, C., Tscharntke, T., 2007. Importance of pollinators in changing landscapes for world crops. Proc. R. Soc. B Biol. Sci. 274. https://doi.org/10.1098/rspb.2006.3721 
Kwak, M.L., Heath, A.C.G., Palma, R.L., 2019. Saving the Manx Shearwater Flea Ceratophyllus (Emmareus) fionnus (Insecta: Siphonaptera): The Road to Developing a Recovery Plan for a Threatened Ectoparasite. Acta Parasitol. 64, 903-910. https://doi.org/10.2478/s11686-019-00119-8

Ladle, R.J., Jepson, P., Correia, R.A., Malhado, A.C.M., 2019. A culturomics approach to quantifying the salience of species on the global internet. People Nat. 1, 524-532. https://doi.org/10.1002/pan3.10053

Launer, A.E., Murphy, D.D., 1994. Umbrella species and the conservation of habitat fragments: A case of a threatened butterfly and a vanishing grassland ecosystem. Biol. Conserv. 69, 145-153. https://doi.org/10.1016/0006-3207(94)90054-X

Leandro, C., Jay-Robert, P., Vergnes, A., 2017. Bias and perspectives in insect conservation: A European scale analysis. Biol. Conserv. 215, 213-224. https://doi.org/10.1016/j.biocon.2017.07.033

Mammola, S., Riccardi, N., Prie, V., Correia, R., Cardoso, P., Lopes-Lima, M., Sousa, R., 2020. Towards a taxonomically unbiased European Union biodiversity strategy for 2030. Proc. R. Soc. B Biol. Sci. 287, 20202166. https://doi.org/10.1098/rspb.2020.2166

Manning, P., Slade, E.M., Beynon, S.A., Lewis, O.T., 2016. Functionally rich dung beetle assemblages are required to provide multiple ecosystem services. Agric. Ecosyst. Environ. 218, 87-94. https://doi.org/10.1016/j.agee.2015.11.007

Martin-Lopez, B., Montes, C., Benayas, J., 2007. The non-economic motives behind the willingness to pay for biodiversity conservation. Biol. Conserv. 139, 67-82. https://doi.org/10.1016/j.biocon.2007.06.005

Martin, J.L., Cardoso, P., Arechavaleta, M., Borges, P.A.V., Faria, B.F., Abreu, C., Aguiar, A.F., Carvalho, J.A., Costa, A.C., Cunha, R.T., Fernandes, F.M., Gabriel, R., Jardim, R., Lobo, C., Martins, A.M.F., Oliveira, P., Rodrigues, P., Silva, L., Teixeira, D., Amorim, I.R., Homem, N., Martins, B., Martins, M., Mendonca, E., 2010. Using taxonomically unbiased criteria to prioritize resource allocation for oceanic island species conservation. Biodivers. Conserv. 19, 1659-1682. https://doi.org/10.1007/s10531-010-9795-z

Metcalfe, D.B., Asner, G.P., Martin, R.E., Silva Espejo, J.E., Huasco, W.H., Farfan Amezquita, F.F., Carranza-Jimenez, L., Galiano Cabrera, D.F., Baca, L.D., Sinca, F., Huaraca Quispe, L.P., Taype, I.A., Mora, L.E., Davila, A.R., Solorzano, M.M., Puma Vilca, B.L., Laupa Roman, J.M., Guerra Bustios, P.C., Revilla, N.S., Tupayachi, R., Girardin, C.A.J., Doughty, C.E., Malhi, Y., 2014. Herbivory makes major contributions to ecosystem carbon and nutrient cycling in tropical forests. Ecol. Lett. 17, 324-332. https://doi.org/10.1111/ele.12233

McKinney, M.L., Lockwood, J.L., 1999. Biotic homogenization: A few winners replacing many losers in the next mass extinction. Trends Ecol. Evol. 14, 450-453. https://doi.org/10.1016/S0169-5347(99)01679-1

Montgomery, G.A., Dunn, R.R., Fox, R., Jongejans, E., Leather, S.R., Saunders, M.E., Shortall, C.R., Tingley, M.W., Wagner, D.L., 2020. Is the insect apocalypse upon us? How to find out. Biol. Conserv. 241, 108327. https://doi.org/10.1016/j.biocon.2019.108327

Morimoto, J., 2020. Addressing global challenges with unconventional insect ecosystem services: Why should humanity care about insect larvae? People Nat. 2, 582-595. https://doi.org/10.1002/pan3.10115

National Biodiversity Data Centre, 2020. Ireland's Red Lists [WWW Document]. URL https://www.biodiversityireland.ie/resources/irish-red-lists/ (accessed 11.4.20).

Natural England, 2014. Section 41 Species - Priority Actions Needed (B2020 - 008) [WWW Document]. URL http://publications.naturalengland.org.uk/publication/4958719460769792 (accessed 5.15.21).

Nature Conservancy Council, 1986. First Quinquennial Review of Schedules 5 and 8: Wildlife and Countryside Act 1981.

NatureScot, 2020. Scottish Biodiversity List [WWW Document]. 
NBN Atlas, 2021. Species List: Scottish Biodiversity List [WWW Document]. URL https://lists.nbnatlas.org/speciesListItem/list (accessed 1.7.21).

Nelson, B., Ronayne, C. \& Thompson, R., 2011. Ireland Red List No.6: Damselflies \& Dragonflies (Odonata). Natl. Park. Wildl. Serv. Dep. Environ. Herit. Local Gov. Dublin, Ireland.

Nelson, B., Cummins, S., Fay, L., Jeffrey, R., Kelly, S., Kingston, N., Lockhart, N., Marnell, F., Tierney, D. and Wyse Jackson, M., 2019. Checklists of protected and threatened species in Ireland. Irish Wildl. Manuals No.116.

Noriega, J.A., Hortal, J., Azcarate, F.M., Berg, M.P., Bonada, N., Briones, M.J.I., Del Toro, I., Goulson, D., Ibanez, S., Landis, D.A., Moretti, M., Potts, S.G., Slade, E.M., Stout, J.C., Ulyshen, M.D., Wackers, F.L., Woodcock, B.A., Santos, A.M.C., 2018. Research trends in ecosystem services provided by insects. Basic Appl. Ecol. 26, 8-23. https://doi.org/10.1016/j.baae.2017.09.006

Obrist, P.D., Martin, K., 1998. In Search of the Best Correlates for Local Organismal Biodiversity in Cultivated Areas. Biodivers. Conserv. 7, 297-309. https://doi.org/10.1023/A:1008873510817

Ollerton, J., Erenler, H., Edwards, M., Crockett, R., 2014. Extinctions of aculeate pollinators in Britain and the role of large-scale agricultural changes. Science (80-. ). 346, 1360-1362. https://doi.org/10.1126/science.1257259

Orford, K.A., Vaughan, I.P., Memmott, J., 2015. The forgotten flies: The importance of non-syrphid Diptera as pollinators. Proc. R. Soc. B Biol. Sci. 282. https://doi.org/10.1098/rspb.2014.2934

Orians, C.M., Thorn, A., Gomez, S., 2011. Herbivore-induced resource sequestration in plants: why bother? Oecologia 167, 1-9. https://doi.org/10.1007/s00442-011-1968-2

Powney, G.D., Carvell, C., Edwards, M., Morris, R.K.A., Roy, H.E., Woodcock, B.A., Isaac, N.J.B., 2019. Widespread losses of pollinating insects in Britain. Nat. Commun. 10. https://doi.org/10.1038/s41467-01908974-9

Ramos Elorduy, J., 2005. Insects: A Hopeful Food Source, in: Paoletti, M. (Ed.), Ecological Implications of Minilivestock: Role of Rodents, Frogs, Snails and Insects for Sustainable Development. Science Publishers, New Hampshire, pp. 263-291.

R Core Team, 2019. R: A language and environment for statistical computing.

Regan, E.C., Nelson, B., Aldwell, B., Bertrand, C., Bond, K., Harding, J., Nash, D., Nixon, D., \& W., C.J, 2010. Ireland Red List No. 4 - Butterflies. Natl. Park. Wildl. Serv. Dep. Environ. Herit. Local Gov. Ireland.

Regnier, C., Bouchet, P., Hayes, K.A., Yeung, N.W., Christensen, C.C., Chung, D.J.D., Fontaine, B., Cowie, R.H., 2015. Extinction in a hyperdiverse endemic Hawaiian land snail family and implications for the underestimation of invertebrate extinction. Conserv. Biol. 29, 1715-1723. https://doi.org/10.1111/cobi.12565

Regnier, C., Fontaine, B., Bouchet, P., 2009. Not Knowing, Not Recording, Not Listing: Numerous Unnoticed Mollusk Extinctions. Conserv. Biol. 23, 1214-1221. https://doi.org/10.1111/j.1523-1739.2009.01245.x

Samways, M.J., Barton, P.S., Birkhofer, K., Chichorro, F., Deacon, C., Fartmann, T., Fukushima, C.S., Gaigher, R., Habel, J.C., Hallmann, C.A., Hill, M.J., Hochkirch, A., Kaila, L., Kwak, M.L., Maes, D., Mammola, S., Noriega, J.A., Orfinger, A.B., Pedraza, F., Pryke, J.S., Roque, F.O., Settele, J., Simaika, J.P., Stork, N.E., Suhling, F., Vorster, C., Cardoso, P., 2020. Solutions for humanity on how to conserve insects. Biol. Conserv. 242, 108427. https://doi.org/10.1016/j.biocon.2020.108427

Sanchez-Bayo, F., 2014. The trouble with neonicotinoids. Science (80-. ）. 346, 806-807. https://doi.org/10.1126/science.1259159 
Seibold, S., Rammer, W., Hothorn, T., Seidl, R., Ulyshen, M.D., Lorz, J., Cadotte, M.W., Lindenmayer, D.B., Adhikari, Y.P., Aragon, R., Bae, S., Baldrian, P., Barimani Varandi, H., Barlow, J., Bassler, C., Beauchene, J., Berenguer, E., Bergamin, R.S., Birkemoe, T., Boros, G., Brandl, R., Brustel, H., Burton, P.J., Cakpo-Tossou, Y.T., Castro, J., Cateau, E., Cobb, T.P., Farwig, N., Fernandez, R.D., Firn, J., Gan, K.S., Gonzalez, G., Gossner, M.M., Habel, J.C., Hebert, C., Heibl, C., Heikkala, O., Hemp, A., Hemp, C., Hjalten, J., Hotes, S., Kouki, J., Lachat, T., Liu, J., Liu, Y., Luo, Y.-H., Macandog, D.M., Martina, P.E., Mukul, S.A., Nachin, B., Nisbet, K., O'Halloran, J., Oxbrough, A., Pandey, J.N., Pavliček, T., Pawson, S.M., Rakotondranary, J.S., Ramanamanjato, J.-B., Rossi, L., Schmidl, J., Schulze, M., Seaton, S., Stone, M.J., Stork, N.E., Suran, B., Sverdrup-Thygeson, A., Thorn, S., Thyagarajan, G., Wardlaw, T.J., Weisser, W.W., Yoon, S., Zhang, N., Müller, J., 2021. The contribution of insects to global forest deadwood decomposition. Nature 597, 77-81. https://doi.org/10.1038/s41586-021-03740-8

Senapathi, D., Biesmeijer, J.C., Breeze, T.D., Kleijn, D., Potts, S.G., Carvalheiro, L.G., 2015. Pollinator conservation - the difference between managing for pollination services and preserving pollinator diversity. Curr. Opin. Insect Sci. 12, 93-101. https://doi.org/10.1016/j.cois.2015.11.002

Schowalter, T.D., 2013. Insects and sustainability of ecosystem services, 1st ed, Insects and Sustainability of Ecosystem Services. CRC Press, Boca Raton. https://doi.org/10.1201/b14911

Shaw, M.R., 2006. Habitat Considerations for Parasitic Wasps (Hymenoptera). J. Insect Conserv. 10, 117127. https://doi.org/10.1007/s10841-006-6288-1

Shaw, M.R., Hochberg, M.E., 2001. The neglect of parasitic Hymenoptera in insect conservation strategies: The British fauna as a prime example. J. Insect Conserv. 5, 253-263. https://doi.org/10.1023/A:1013393229923

Slowikowski, K., 2020. ggrepel: Automatically Position Non-Overlapping Text Labels with "ggplot2". R package version 0.8.2.

Sluijs, J.P. der, Simon-Delso, N., Goulson, D., Maxim, L., Bonmatin, J.-M., Belzunces, L.P., 2013. Neonicotinoids, bee disorders and the sustainability of pollinator services. Curr. Opin. Environ. Sustain. 5, 293-305. https://doi.org/10.1016/j.cosust.2013.05.007

Soliveres, S., Van Der Plas, F., Manning, P., Prati, D., Gossner, M.M., Renner, S.C., Alt, F., Arndt, H., Baumgartner, V., Binkenstein, J., Birkhofer, K., Blaser, S., Blüthgen, N., Boch, S., Böhm, S., Börschig, C., Buscot, F., Diekötter, T., Heinze, J., Hölzel, N., Jung, K., Klaus, V.H., Kleinebecker, T., Klemmer, S., Krauss, J., Lange, M., Morris, E.K., Müller, J., Oelmann, Y., Overmann, J., Pašalić, E., Rillig, M.C., Schaefer, H.M., Schloter, M., Schmitt, B., Schöning, I., Schrumpf, M., Sikorski, J., Socher, S.A., Solly, E.F., Sonnemann, I., Sorkau, E., Steckel, J., Steffan-Dewenter, I., Stempfhuber, B., Tschapka, M., Türke, M., Venter, P.C., Weiner, C.N., Weisser, W.W., Werner, M., Westphal, C., Wilcke, W., Wolters, V., Wubet, T., Wurst, S., Fischer, M., Allan, E., 2016. Biodiversity at multiple trophic levels is needed for ecosystem multifunctionality. Nature 536, 456-459. https://doi.org/10.1038/nature19092

Spitzer, L., Benes, J., Dandova, J., Jaskova, V., Konvicka, M., 2009. The Large Blue butterfly, Phengaris [Maculinea] arion, as a conservation umbrella on a landscape scale: The case of the Czech Carpathians. Ecol. Indic. 9, 1056-1063. https://doi.org/10.1016/j.ecolind.2008.12.006

Ssymank, A., Kearns, C.A., Pape, T., Thompson, F.C., 2008. Pollinating flies (diptera): A major contribution to plant diversity and agricultural production. Biodiversity 9, 86-89. https://doi.org/10.1080/14888386.2008.9712892

Sumner, S., Law, G., Cini, A., 2018. Why we love bees and hate wasps. Ecol. Entomol. 43, 836-845. https://doi.org/10.1111/een.12676

Sutherland, W.J., Albon, S.D., Allison, H., Armstrong-Brown, S., Bailey, M.J., Brereton, T., Boyd, I.L., Carey, P., Edwards, J., Gill, M., Hill, D., Hodge, I., Hunt, A.J., Le Quesne, W.J.F., Macdonald, D.W., Mee, L.D., Mitchell, R., Norman, T., Owen, R.P., Parker, D., Prior, S. V., Pullin, A.S., Rands, M.R.W., 
Redpath, S., Spencer, J., Spray, C.J., Thomas, C.D., Tucker, G.M., Watkinson, A.R., Clements, A., 2010. The identification of priority policy options for UK nature conservation. J. Appl. Ecol. 47, 955-1158. https://doi.org/10.1111/j.1365-2664.2010.01863.x

Sutherland, W.J., Pullin, A.S., Dolman, P.M., Knight, T.M., 2004. The need for evidence-based conservation. Trends Ecol. Evol. 19, 305-308. https://doi.org/10.1016/j.tree.2004.03.018

Swaay, C.A.M. van, Nowicki, P., Settele, J., Strien, A.J. van, 2008. Butterfly monitoring in Europe: methods, applications, and perspectives. Biodivers. Conserv. 17, 3455-3469. https://doi.org/10.1007/s10531-008-94914

Tallamy, D., Narango, D., Mitchell, A., 2021. Do non-native plants contribute to insect declines? Ecol. Entomol. 46, 729-742. https://doi.org/10.1111/een.12973

Thomas, J.A., Morris, M.G., 1997. Patterns, mechanisms and rates of extinction among invertebrates in the United Kingdom. Philos. Trans. R. Soc. B Biol. Sci. 344, 47-54. https://doi.org/10.1098/rstb.1994.0050

Thomas, J.A., Telfer, M.G., Roy, D.B., Preston, C.D., Greenwood, J.J.D., Asher, J., Fox, R., Clarke, R.T., Lawton, J.H., 2004. Comparative Losses of British Butterflies, Birds, and Plants and the Global Extinction Crisis. Science (80-. ). 303, 1879-1881. https://doi.org/10.1126/science.1095046

van der Sluijs, J.P., 2020. Insect decline, an emerging global environmental risk. Curr. Opin. Environ. Sustain. 46, 39-42. https://doi.org/10.1016/j.cosust.2020.08.012

van Klink, R., Bowler, D.E., Gongalsky, K.B., Swengel, A.B., Gentile, A., Chase, J.M., 2020. Meta-analysis reveals declines in terrestrial but increases in freshwater insect abundances. Science (80-. ). 368, 417-420. https://doi.org/10.1126/science.aax9931

Vanbergen, A.J., 2013. Threats to an ecosystem service: pressures on pollinators. Front. Ecol. Environ. 11, 251-259. https://doi.org/10.1890/120126

Wales Biodiversity Partnership, 2021. Environment (Wales) Act 2016 [WWW Document]. URL https://www.biodiversitywales.org.uk/Environment-Wales-Act (accessed 5.15.21).

Wickham, H., 2016. ggplot2: Elegant Graphics for Data Analysis.

Winfree, R., Williams, N.M., Dushoff, J., Kremen, C., 2007. Native bees provide insurance against ongoing honey bee losses. Ecol. Lett. 10, 1105-1113. https://doi.org/10.1111/j.1461-0248.2007.01110.x

Figures: 


\begin{tabular}{|c|c|c|}
\hline Country of Origin & Policy & Obligations \\
\hline \multirow{7}{*}{$\begin{array}{l}\text { Northern } \\
\text { Ireland, U }\end{array}$} & $\begin{array}{l}\text { Wildlife and } \\
\text { Countryside Act } 1981\end{array}$ & $\begin{array}{l}\text { Restricts killing, taking, disturbance, or } \\
\text { trade of Schedule } 5 \text { species, including } \\
\mathbf{4 8} \text { species of insect. }\end{array}$ \\
\hline & $\begin{array}{l}\text { Natural Environment } \\
\text { and Rural } \\
\text { Communities Act } 2006\end{array}$ & $\begin{array}{l}\text { Necessitates a duty to conserve } \\
\text { biodiversity. Lists } \mathbf{3 2 2} \text { insects as 'of } \\
\text { principal importance for conservation' }\end{array}$ \\
\hline & $\begin{array}{l}\text { Nature Conservation } \\
\text { (Scotland) Act } 2004\end{array}$ & $\begin{array}{l}\text { Necessitates a duty to conserve } \\
\text { biodiversity. Lists } \mathbf{3 4 2} \text { insects as 'of } \\
\text { principal importance for conservation' }\end{array}$ \\
\hline & $\begin{array}{l}\text { Environment Act } \\
\text { (Wales) } 2016\end{array}$ & $\begin{array}{l}\text { Necessitates a duty to conserve } \\
\text { biodiversity. Lists } 167 \text { insects as 'of } \\
\text { principal importance for conservation' }\end{array}$ \\
\hline & $\begin{array}{l}\text { Wildlife and Natural } \\
\text { Environment (NI) Act } \\
2011 \\
\end{array}$ & $\begin{array}{l}\text { Necessitates a duty to conserve } \\
\text { biodiversity. Lists } 143 \text { insects as 'of } \\
\text { principal importance for conservation' }\end{array}$ \\
\hline & $\begin{array}{l}\text { Wildlife Order } 1985 \& \\
\text { Conservation } \\
\text { Regulations } 1995\end{array}$ & $\begin{array}{l}\text { Restricts killing, taking, disturbance, or } \\
\text { trade of Schedule } 5 \text { species, including } 9 \\
\text { species of insect. }\end{array}$ \\
\hline & Wildlife Act 1976 & $\begin{array}{l}\text { Restricts killing, taking, disturbance, or } \\
\text { trade of Schedule } 5 \text { species, includes no } \\
\text { species of insect. }\end{array}$ \\
\hline
\end{tabular}

Figure 1. Map of policies analysed in this study. Policies identified in the United Kingdom and Ireland that explicitly protect species, or have obligations prioritising the conservation of species.

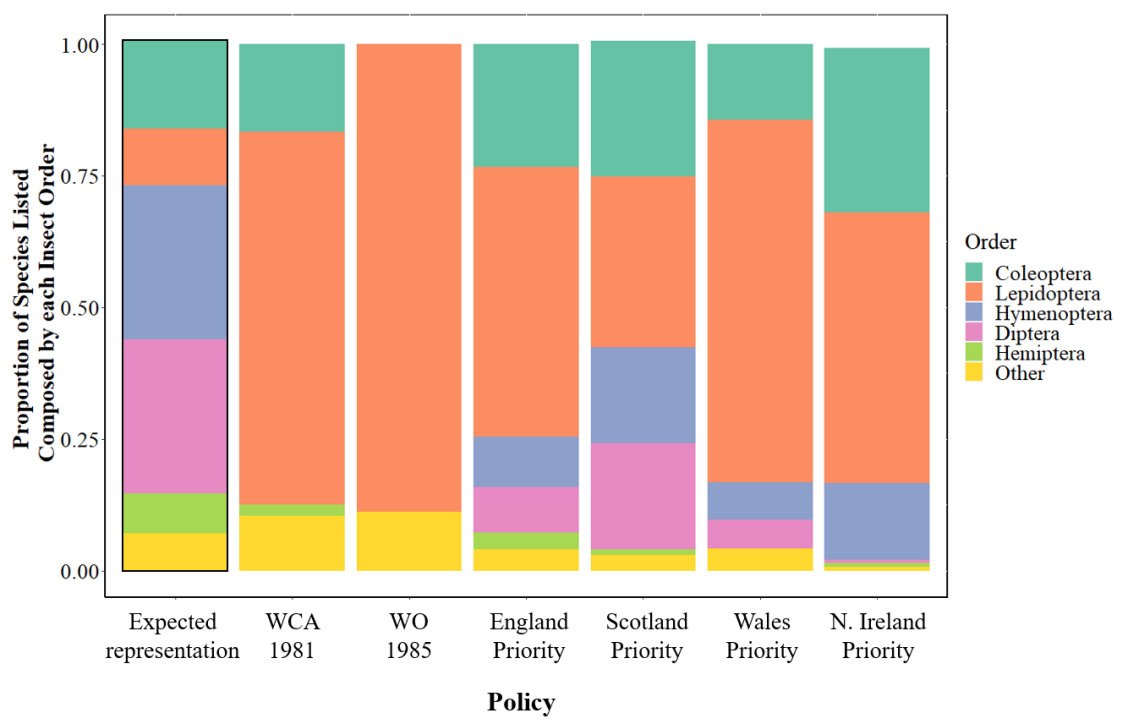

Figure 2. Differences between species composition of UK policies and the expected composition based upon the UK entomofauna. The expected order representation of policies (assuming equal extinction risk in each insect order), and the observed order representation of insects protected by the Wildlife and Countryside Act $1981(N=48)$, the Wildlife Order $1985(N=9)$, or listed as 'of principal importance for conservation' in England $(N=322)$, Scotland $(N=342)$, Wales $(N=167)$, and Northern Ireland $(N=143)$. 

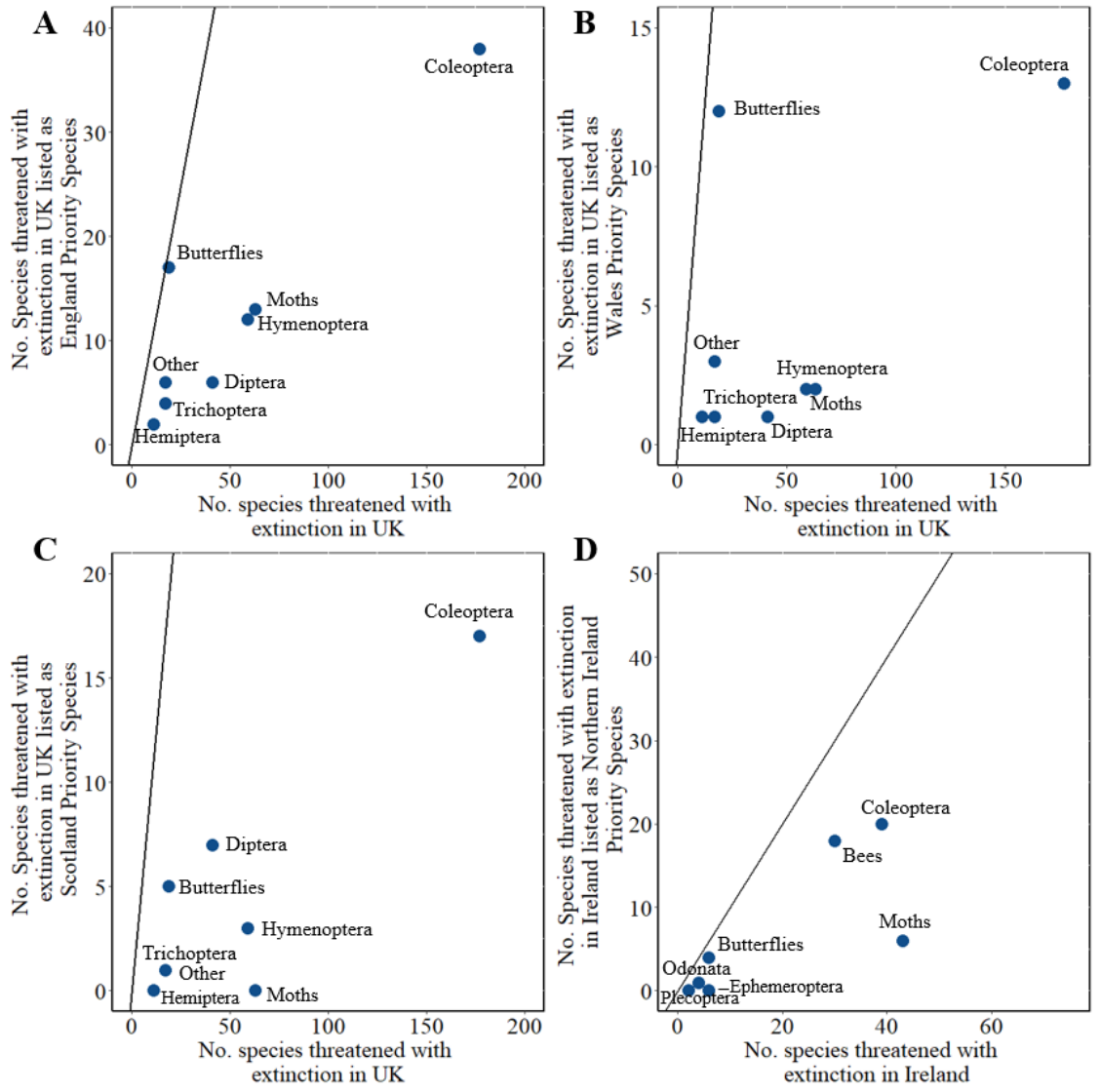

Figure 3. Insect species threatened with extinction and their place within priority lists. The number of insect species classified as vulnerable, endangered, or critically endangered according to UK and Ireland level IUCN-style assessments of insects, and how many of those are listed as a species 'of principal importance for conservation' in (a) England, (b) Wales, (c) Scotland, (d)Northern Ireland. 

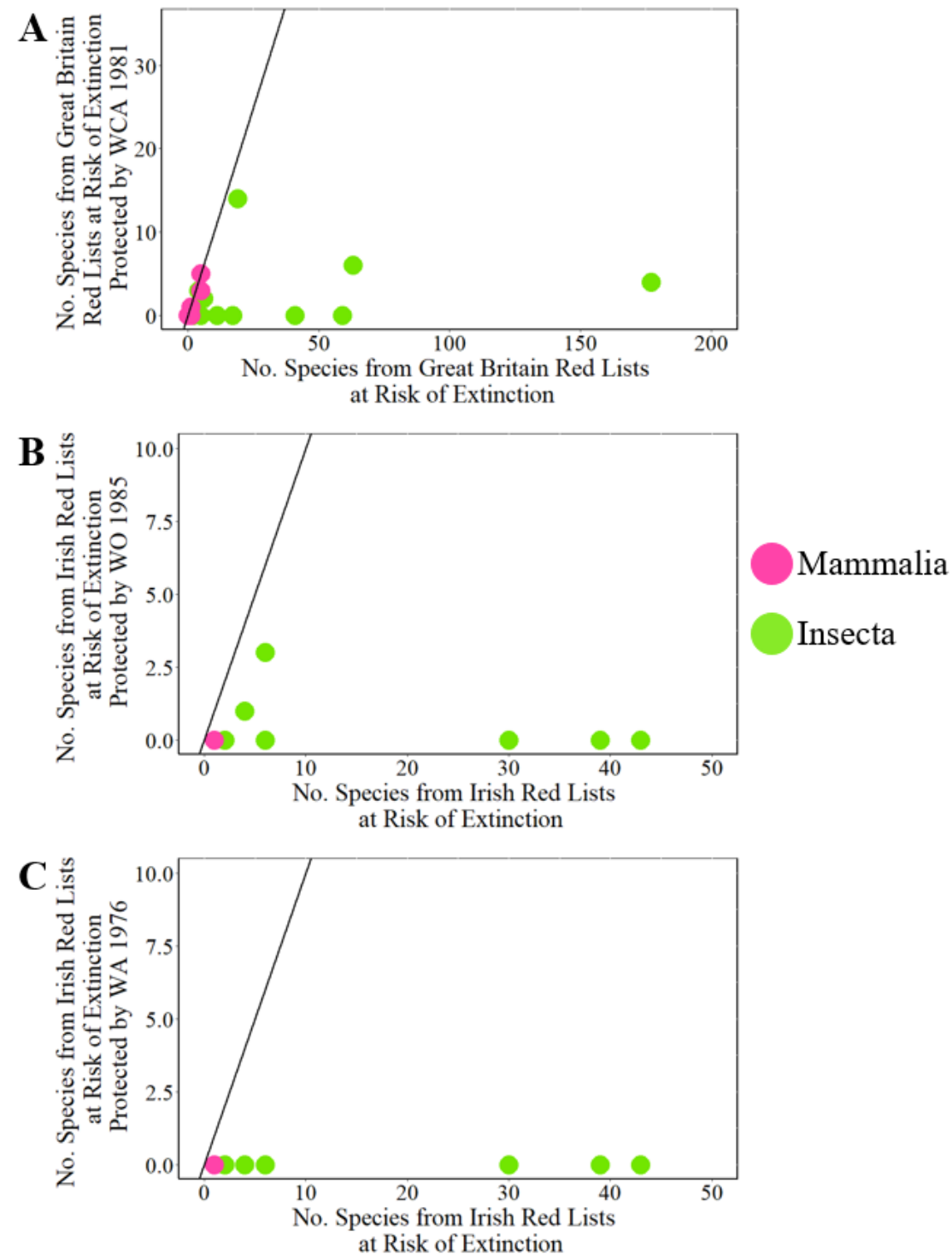

Figure 4. Insect versus mammal coverage of UK and Irish policies for species conservation using regional red lists. The number of insect and mammal species listed on the Great British and Irish red lists as Vulnerable, Endangered, or Critically Endangered, plotted against the number of those which are protected by $(a)$ Schedule 5 of the Wildlife and Countryside Act 1981 (Great Britain) (b) Schedule 5 of the Wildlife Order 1985 and Schedule 2 of the Conservation Regulations 1995 (Northern Ireland) $(c)$ Schedule 5 of the Wildlife Act 1976 (Ireland). 


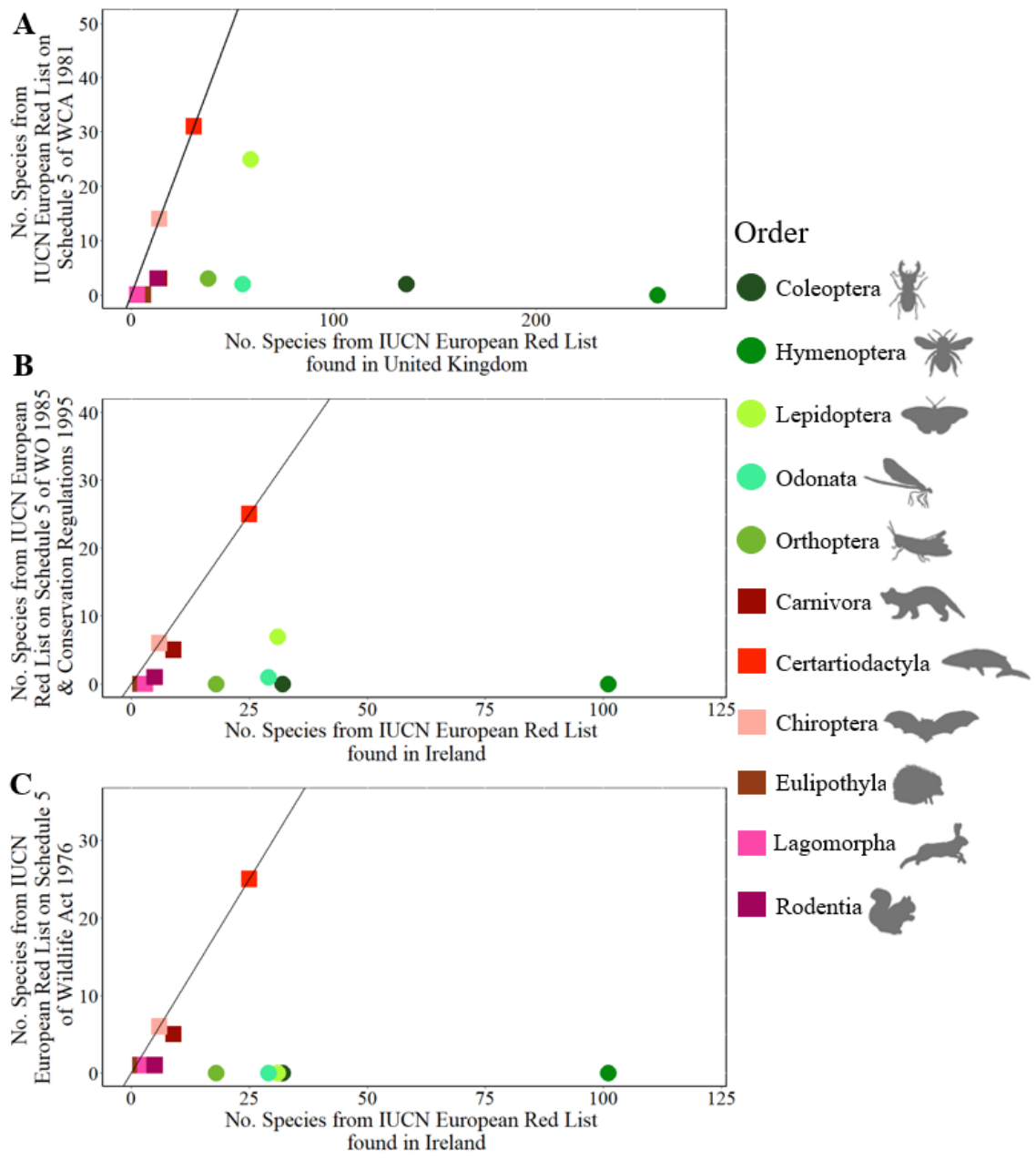

Figure 5. Insect versus mammal coverage of UK and Irish policies for species conservation. The number of insect and mammal species listed on the IUCN Red List for Europe plotted against the number of those which are protected by $(a)$ Schedule 5 of the Wildlife and Countryside Act 1981 (Great Britain) (b ) Schedule 5 of the Wildlife Order 1985 and Schedule 2 of the Conservation Regulations 1995 (Northern Ireland) (c ) Schedule 5 of the Wildlife Act 1976 (Ireland).

\section{Supplementary Material}

Table S1. Raw policy data, IUCN data, and R data input (separate file).

Figure S1. Workflow of data to analysis outputs.

Table S2. Entomofauna representativity data used for Chi-Squared analysis (separate file).

R script . R script (separate file). 